This is an Open Access article under the CC BY-SA license (http://creativecommons.org/licenses/by-sa/4.0/)

\title{
PENGARUH PEMIJATAN TERHADAP KUALITAS TIDUR BAYI USIA 3-4 BULAN DI POSYANDU GELATIK DAN NURI KELURAHAN TANJUNGUNGGAT WILAYAH KERJA PUSKESMAS SEI JANG KOTA TANJUNGPINANG TAHUN 2014 (The Effects of Massage on the Quality of Sleeping in Babies 3-4 Months Old at Gelatik and Nuri IHCs of Tanjung Unggat Village of Tanjungpinang in 2014)
}

\author{
Utami Dewi, Fidyah Aminin, Harvensica Gunnara \\ Poltekkes Kemenkes Tanjungpinang \\ utamidewi_poltek@yahoo.co.id
}

\begin{abstract}
Sleep is an essential need that must be met, especially in the development phase since brain and body development will occur during sleep. Thus, sleep disturbance is a problem that will cause adverse effects on growth and development, especially for babies. Sleep quality for babies can be improved by providing baby massage on a regular basis. The purpose of this study was to prove whether there were differences in sleep quality before and after the massage in babies aged 3-4 months in Gelatik and Nuri IHC (Integrated Health Center) of Tanjungunggat Village of Tanjungpinang Municipality. Design: This was a Quasi Experiment study with a pretest-posttest method. The sample consisted of 17 respondents selected by purposive sampling technique. The statistical test used in this study was a dependent t-test with a significance level of 0.05.Result: The results showed that there was no significant difference between baby sleep duration before and after the massage $(p=0.414)$. However, there was significant difference between the frequency of waking up before and after the massage $(p=0.001)$ and there was a significant difference between the duration of waking up before and after the massage ( $p=$ 0.046. Discuss: Based on the results of this study, it is suggested that mothers should improve their knowledge on the importance of baby massage provided by health professionals and the health professionals should provide and demonstrate clear, complete and sustained information to the mothers and other related parties surrounding the IHC.
\end{abstract}

Keywords: Quality of sleep, massage, babies aged 3-4 months

Convention on The Right of The Child (CRC) yang telah disahkan oleh Majelis Umum Perserikatan Bangsa-Bangsa (PBB) Tahun 1989 mencakup tiga nilai utama yaitu perlindungan (protection), nilai kelangsungan hidup (survival) dan nilai perkembangan (development) anak. Pemerintah Indonesia sebagai salah satu negara yang telah memantapkan CRC sebagai Undang-Undang Republik Indonesia yaitu Nomor 23 Tahun 2002 tentang Perlindungan Anak yang menyatakan bahwa setiap anak berhak memperoleh pelayanan kesehatan dan jaminan sosial sesuai dengan kebutuhan fisik, mental, spiritual dan sosial (Abidin, 2009)

Tidak dapat dipungkiri bahwa anak merupakan tumpuan harapan masa depan.
Kelangsungan hidup anak masih menjadi barang mahal, khususnya di beberapa negara. Ancaman terhadap kelangsungan hidup anak tercermin pada gangguan pertumbuhan dan perkembangan. Upaya kesehatan yang dilakukan sejak anak masih dalam kandungan sampai lima tahun pertama kehidupannya ditujukan untuk mempertahankan kelangsungan hidupnya sekaligus meningkatkan kualitas hidup anak agar mencapai tumbuh kembang optimal baik fisik, mental, emosional maupun sosial serta memiliki intelegensi majemuk sesuai dengan potensi genetiknya.

Kualitas tumbuh kembang balita di Indonesia perlu mendapatkan perhatian serius yang salah satunya adalah stimulasi yang 144 
memadai artinya merangsang otak balita sehingga perkembangan kemampuan gerak, bicara dan bahasa, sosialisasi dan kemandirian pada balita berlangsung secara optimal sesuai dengan umur anak. Aktifitas tidur merupakan salah satu stimulus bagi proses tumbuh kembang otak, karena 75 persen hormon pertumbuhan dikeluarkan pada saat anak tidur. Hormon pertumbuhan ini yang bertugas merangsang pertumbuhan tulang dan jaringan. Selain itu, hormon pertumbuhan juga memungkinkan tubuh memperbaiki dan memperbarui seluruh sel yang ada di tubuh, dari sel kulit, sel darah sampai sel saraf otak. Proses pembaruan sel ini akan berlangsung lebih cepat bila si bayi sering terlelap sesuai dengan kebutuhan tidur bayi. Selain itu, tidur juga membantu perkembangan psikis emosi, kognitif, konsolidasi pengalaman dan kecerdasan. Oleh karena itu kebutuhan tidur pada bayi sesuai usianya perlu mendapat perhatian dari keluarga agar nantinya bayi dapat mencapai pertumbuhan dan perkembangan yang optimal (Hurlock, 1997)

Kualitas tidur bayi tidak hanya berpengaruh pada perkembangan fisik, tapi juga sikapnya keesokan hari. Bayi yang tidur cukup tanpa sering terbangun akan lebih bugar dan tidak gampang rewel. Bayi dikatakan mengalami gangguan tidur jika pada malam hari tidurnya kurang dari 9 jam, terbangun lebih dari 3 kali dan lamanya terbangun lebih dari 1 jam. Selama tidur bayi terlihat selalu rewel, menangis dan sulit tidur kembali. (Wahyuni, 2008)

Bayi sekitar umur 3-4 bulan memerlukan waktu untuk tidur kurang lebih 18 jam perhari dan waktu yang tersisa untuk bayi adalah bermain dan melakukan aktifitas yang membuat bayi nyaman, misalnya bercengkrama dengan ibu dan anggota keluarga. Tetapi masalah yang dialami ibu lainnya adalah permasalahan bagi bayi yang sulit sekali untuk tidur di malam hari dan jika tidak ditangani dengan serius ada gangguan perilaku, tumbuh kembang serta gangguan otak (Ismael, 1994)

Kualitas dan kuantitas tidur bayi dipengaruhi oleh beberapa faktor. Kualitas tersebut dapat menunjukkan adanya kemampuan individu untuk tidur dan memperoleh jumlah istirahat sesuai dengan kebutuhannya yaitu lingkungan, latihan fisik, nutrisi dan Penyakit. Mengingat akan pentingnya waktu tidur bagi perkembangan bayi, maka kebutuhan tidurnya harus benarbenar terpenuhi agar tidak berpengaruh buruk terhadap perkembangannya. Salah satu cara yang dapat digunakan untuk memenuhi kebutuhan tersebut adalah dengan latihan fisik atau pijatan. Bayi yang dipijat akan dapat tidur dengan lelap, sedangkan pada waktu bangun, daya konsentrasinya akan lebih penuh (Roesli, 2001)

Menurut Undang-Undang Kesehatan Nomor 36 Tahun 2009, pijat bayi merupakan pelayanan kesehatan tradisional yang termasuk dalam jenis keterampilan. Pijat bayi ini sesuai dengan Permenkes Nomor 1109 Tahun 2007 dapat dikategorikan kedalam pengobatan komplementer-alternatif karena sudah diperoleh melalui pendidikan terstruktur yang berlandaskan ilmu pengetahuan biomedik. Pijat bayi adalah suatu bentuk permainan gerakan pada bayi, untuk merangsang pertumbuhan dan perkembangan serta kemampuan pergerakan bayi secara optimal (sutini, 2008)

Berdasarkan wawancara yang dilakukan di 6 puskesmas yang ada di kota Tanjungpinang didapat informasi bahwa pijat bayi belum dilakukan secara rutin dalam kegiatan pelayanan KIA, dari data jumlah bayi yang lahir pada bulan Januari-Maret 2014 di Kota Tanjungpinang terbanyak di Puskesmas Sei Jang yaitu 417 kelahiran bayi dan jumlah bayi terbanyak ada di Posyandu Gelatik dan Nuri. Berdasarkan latar belakang diatas maka peneliti tertarik untuk mengetahui pengaruh pemijatan terhadap kualitas tidur bayi usia 3-4 bulan.

\section{BAHAN DAN METODE}

Desain penelitian yang digunakan dalam penelitian ini adalah quasi eksperiment dengan rancangan One Group pre and post test design yaitu observasi dilakukan sebelum dan sesudah diberikan perlakuan pada responden.

Penelitian ini dilakukan di Posyandu Gelatik dan Nuri Kelurahan Tanjungunggat wilayah kerja Puskesmas Sei Jang Kota Tanjungpinang bulan September-November 2014

Populasi dalam penelitian ini adalah semua bayi berusia 3-4 bulan di Posyandu 
Gelatik dan Nuri Kelurahan Tanjungunggat wilayah kerja puskesmas Sei Jang Kota Tanjungpinang berjumlah 17 orang

Teknik pengambilan sampel dalam penelitian ini menggunakan cara Non Probability Sampling-Purpossive Sampling Type dimana peneliti memilih responden berdasarkan pada pertimbangan subjektif, bahwa responden tersebut dapat memberikan informasi yang memadai untuk menjawab pertanyaan penelitian. Adapun yang termasuk kriteria dalam penelitian ini adalah:

a. Bayi usia 3-4 bulan

b. Bayi dalam keadaan sehat

c. Berat badan sesuai dengan umur

d. Bayi masih mendapatkan ASI

e. Ibu bayi bersedia menjadi responden

Teknik pengumpulan data dilakukan dengan wawancara oleh peneliti dan observasi oleh ibu bayi. Wawancara dengan menggunakan lembar pedoman wawancara yang dilakukan pada awal penelitian untuk mengetahui tentang identitas responden, kebiasaan minum susu bayi, kesehatan bayi, berat badan bayi saat penelitian dan kesediaan ibu untuk dilakukan pemijatan. Data dikumpulkan melalui observasi pada responden yang diteliti.

Pada pretest responden diobservasi kualitas tidur satu hari sebelum dilakukan pemijatan meliputi lama tidur, frekuensi terbangun, dan lama terbangun selama 24 jam yang dilakukan oleh ibu bayi. Pada posttest responden setelah diberi perlakuan pemijatan setiap hari selama 6 hari diobservasi kualitas tidurnya, meliputi lama tidur, frekuensi terbangun dan lama terbangun selama 24 jam yang dilakukan oleh ibu bayi. Pemijatan dilakukan oleh peneliti. Sebelum dilakukan observasi ibu bayi diberikan pengarahan mengenai cara mengobservasi kualitas tidur.

Analisis data yang dipergunakan dalam penelitian ini dilakukan secara bertahap meliputi

a. Univariabel dilakukan dengan statistik deskriptif untuk melihat frekuensi dan distribusi variabel bebas, variabel terikat yang diteliti. Tabel frekuensi digunakan untuk menggambarkan karakteristik subjek penelitian dengan melakukan pengkategorian variabel yang dianalisis. Gambaran karakteristik subjek meliputi kualitas tidur bayi dilihat dari lama tidur, frekuensi terbangun dan lama terbangun.

b. Bivariabel dengan mengidentifikasi hubungan antara variabel bebas (pemijatan bayi) dengan variabel terikat (kualitas tidur). Uji statistik yang digunakan adalah t-test dependent dengan tingkat signifikansi 0,05 .

\section{HASIL PENELITIAN}

Responden pada penelitian ini berjumlah 17 orang. Karakteristik responden ditunjukkan dalam tabel 1 dibawah ini

Tabel 1 Distribusi Karakteristik Responden berdasarkan Jenis Kelamin Bayi, Pendidikan dan Pekerjaan Ibu

\begin{tabular}{lcc}
\hline $\begin{array}{l}\text { Karakteristik } \\
\text { Responden }\end{array}$ & Frekuensi & Persen $(\%)$ \\
\hline Jenis Kelamin & & \\
Perempuan & 11 & 64,7 \\
Laki-laki & 6 & 35,3 \\
Pendidikan & & \\
SD & 1 & 5,9 \\
SLTP & 2 & 11,7 \\
SLTA & 13 & 76,5 \\
Akademi & 1 & 5,9 \\
Pekerjaan & & \\
Bidan & 1 & 5,9 \\
IRT & 14 & 82,3 \\
Swasta & 2 & 11,8 \\
\hline
\end{tabular}

Tabel 1 menunjukkan bahwa jumlah bayi perempuan lebih banyak yaitu $64,7 \%$ dibanding laki-laki $35,3 \%$, Analisis tingkat pendidikan ibu, sebagian besar ibu bayi dengan pendidikan SLTA (76,5\%). Tingginya tingkat pendidikan responden seharusnya tidak menjadi masalah bagi pemberi pelayanan kesehatan memberikan informasi atau pendidikan kesehatan. Pekerjaan ibu terbanyak adalah ibu rumah tangga sebesar $82,3 \%$

Tabel 2 Distribusi Lama Tidur Bayi Usia 3-4 Bulan Sebelum dan Sesudah Pemijatan

\begin{tabular}{llllll}
\hline Variabel & Mean & Beda & SD & N & $P$ \\
\hline
\end{tabular}




\begin{tabular}{cccccc}
\hline $\begin{array}{c}\text { Lama Tidur } \\
\text { Sebelum } \\
\text { Lama Tidur } \\
\text { Sesudah }\end{array}$ & 10.06 & 0,32 & 1.676 & 17 & 0.414 \\
\hline
\end{tabular}

Tabel 2 menunjukkan bahwa dari 17 responden sebelum dilakukan pemijatan, ratarata lama tidur bayi adalah 10.06 jam dimalam hari dengan standar deviasi 1,676 dan sesudah dilakukan pemijatan rata-rata lama tidur bayi adalah jam 10.38 jam dimalam hari dengan standar deviasi 0,781. Dari hasil uji t-test didapatkan nilai $p=0,414$ dimana $p>0,05$ maka dapat disimpulkan tidak ada perbedaan yang bermakna antara lama tidur bayi sebelum dan sesudah pemijatan.

Tabel 3 Distribusi Frekuensi Terbangun Bayi Usia 3-4 Bulan Sebelum dan Sesudah Pemijatan

\begin{tabular}{|c|c|c|c|c|c|}
\hline Variabel & Mean & Beda & SD & $\mathrm{N}$ & $P$ \\
\hline Frekuensi & & \multirow{4}{*}{0,82} & & & \multirow{4}{*}{0.001} \\
\hline Terbangun & 2.88 & & 1.166 & 17 & \\
\hline $\begin{array}{l}\text { Sebelum } \\
\text { Frekuensi }\end{array}$ & & & & & \\
\hline $\begin{array}{l}\text { Terbangun } \\
\text { Sesudah }\end{array}$ & 2.06 & & 0.899 & 17 & \\
\hline
\end{tabular}

Tabel 3 diatas menunjukkan bahwa dari 17 responden sebelum dilakukan pemijatan rata-rata frekuensi terbangun bayi adalah $2.88 \mathrm{kali} / \mathrm{hari}$ dengan standar deviasi 1,166 dan sesudah dilakukan pemijatan, ratarata frekuensi terbangun bayi adalah 2.06 kali/hari dengan standar deviasi 0,899. Dari hasil uji $t$-test didapatkan nilai $p=0,001$ dimana $p<0,05$, maka dapat disimpulkan ada perbedaan yang bermakna antara frekuensi terbangun bayi dimalam hari sebelum dan sesudah pemijatan.

Tabel. 4 Distribusi Lama Terbangun Bayi Usia 3-4 Bulan Sebelum dan Sesudah Pemijatan

\begin{tabular}{cccccc}
\hline Variabel & Mean & Beda & SD & N & $P$ \\
\hline $\begin{array}{c}\text { Lama } \\
\text { Terbangun } \\
\text { Sebelum }\end{array}$ & 13.82 & & 8.755 & 17 & \\
$\begin{array}{c}\text { Lama terbangun } \\
\text { Sesudah }\end{array}$ & 11.18 & 2,64 & & & 0.046 \\
\hline
\end{tabular}

Tabel 4 menunjukkan bahwa dari 17 responden sebelum dilakukan pemijatan, ratarata lama terbangun responden adalah 13.82 menit dengan standar deviasi 8,755 dan sesudah dilakukan pemijatan rata-rata lama terbangun responden adalah 11.18 menit

\section{PEMBAHASAN}

\section{Kualitas Tidur Berdasarkan Lama Tidur Bayi}

Tidur adalah proses fisiologis yang bersiklus bergantian dengan periode yang lebih lama dari keterjagaan (Perry et al, 2006). Jumlah lama tidur tiap kelompok usia juga berbeda-beda tergantung faktor fisik, psikis dengan standar deviasi 7,812. Dari hasil uji $t$ test didapatkan nilai $p=0,046$ dimana $p<$ 0,05 , maka dapat disimpulkan ada perbedaan yang bermakna antara lama terbangun bayi dimalam hari sebelum dan sesudah pemijatan.

dan lingkungan. Bayi umur 3-4 bulan memerlukan waktu tidur kurang lebih 16,5 jam perhari dan waktu yang tersisa untuk bayi adalah bermain dan melakukan aktifitas yang membuat bayi nyaman, misalnya bercengkrama dengan ibu dan anggota keluarga (Ismael, 1994) 
Berdasarkan hasil penelitian ada peningkatan rata-rata lama tidur bayi sebelum dan sesudah pemijatan. Penelitian ini dilakukan pada bayi-bayi tanpa gangguan tidur sehingga secara statistik tidak ada perbedaan yang bermakna antara lama tidur bayi sebelum dan sesudah pemijatan. Penelitian yang sama dilakukan oleh Roekistiningsih (2006) bahwa ada peningkatan lama tidur bayi sebelum dipijat yaitu 10,79 jam dan 12,91 jam setelah dilakukan pemijatan namun secara statistik tidak ada perbedaan lama tidur pada bayi yang diberi perlakuan pemijatan dan yang tidak diberi pemijatan.

Peningkatan lama tidur pada bayi yang diberi pemijatan tersebut disebabkan oleh adanya peningkatan kadar sekresi serotonin yang dihasilkan pada saat pemijatan. Serotonin merupakan zat transmitter utama yang menyertai pembentukan tidur dengan menekan aktivitas sistem pengaktivasi retikularis maupun aktivitas otak lainnya, serotonin yang disintesis dari asam amino triptrophan akan diubah menjadi 5hidroksitriptophan (5HTP) kemudian menjadi $\mathrm{N}$-asetil serotonin yang pada akhirnya berubah menjadi melatonin. Melatonin mempunyai peran dalam tidur dan membuat tidur lebih lama (Pierpoli et al, 1995).

Dengan pemijatan yang diberikan akan terjadi dilatasi pembuluh darah, dimana sirkulasi darah akan meningkat. Sirkulasi darah yang lancar akan membutuhkan O2 yang lebih banyak dalam aliran darah, kebutuhan $\mathrm{O} 2$ yang meningkat akan dikirim keseluruh tubuh, tidak terkecuali lebih banyak dikirim ke otak sehingga memacu sistem sirkulasi dan respirasi menjadi lebih baik. Proses ini akan meningkatkan jumlah tidur bayi (Nuviala,1992).

Terdapat beberapa faktor yang ikut mempengaruhi lama tidur bayi mencakup faktor internal dan eksternal. Faktor eksternal diantaranya adalah lingkungan, lingkungan yang ramai dan tidak kondusif akan mempengaruhi lama tidur bayi tersebut. Pada penelitian ini faktor lingkungan tidak dikendalikan secara ketat, sehingga ketika dilakukan pemijatan tidak terdapat perubahan lama tidur yang berarti.

\section{Kualitas Tidur Berdasarkan Frekuensi Terbangan}

Kualitas tidur bayi adalah mutu atau keadaan fisiologis tertentu yang didapatkan selama seseorang tertidur, yang memulihkan proses-proses tubuh yang terjadi pada waktu orang itu bangun. Jika kualitas tidurnya bagus artinya fisiologi/faal tubuh dalam hal ini sel otak misalnya pulih kembali seperti semula saat bangun tidur (Candra, 2005).

Pada penelitian ini bayi yang mendapatkan perlakuan pijat bayi mengalami penurunan frekuensi terbangun dan tidur lebih nyenyak. Rata-rata frekuensi terbangun sebelum dipijat 2,88 mengalami penurunan menjadi 2.06. Bayi dikatakan terganggu tidurnya apabila terbangun lebih dari 3 kali, pada penelitian ini frekuensi terbangun bayi masih dalam batas normal. Setelah mendapat perlakuan pemijatan. Pijatan dapat mengubah gelombang otak, pijat bayi akan membuat bayi tidur lebih lelap dan meningkatkan kesiagaan (allertness) atau konsentrasi karena dapat mengubah gelombang otak dengan cara menurunkan gelombang beta serta tetha.

Menurut Staeker, P. (1999), yang menyatakan bahwa pijat dapat mempengaruhi keluarnya hormon tidur (melatonin), dimana dengan hormon tersebut bayi dapat memiliki pola tidur yang teratur. Melatonin adalah hormon utama yang dihasilkan oleh kelenjar pineal. Sekresinya distimulasi oleh gelap dan dihambat oleh cahaya, melatonin ini meningkat pada malam hari, produksi melatonin meningkat bila reseptor sel tubuh manusia menangkap pesan bahwa intensitas cahaya mulai berkurang. Manfaat lain melatonin adalah sebagai antioksidan yang larut dalam lemak dan air, meningkatkan imun tubuh, menimbulkan relaksasi otot dan menghilangkan ketegangan.

Kebiasaan minum susu sebelum tidur juga akan berpengaruh terhadap kualitas tidur karena susu mengandung alfa protein yang dapat meningkatkan kadar triptophan, tryptophan merupakan prekursor dari hormone melatonin dan serotonin yang bertugas sebagai penghubung antar syaraf (neurotransmitter) serta pengatur kebiasaan (neurobehavioral) yang berpengaruh pada pola kesadaran sehingga membuat bayi akan lebih sering terbangun dimalam hari. Pada penelitian ini kebiasaan minum susu sebelum 
tidur tidak dikendalikan secara ketat karena observasi frekuensi bayi terbangun dimalam hari dilakukan oleh ibu bayi.

Berdasarkan data pendukung dari hasil wawancara dengan ibu masing-masing bayi didapatkan data bahwa bayi mereka tidurnya lebih tenang, lebih aktif bermain disiang hari dan banyak yang sudah mulai dapat menyebutkan 1 sampai 2 suku kata. Hal ini sesuai dengan pendapat wahyuni (2008) bahwa kualitas tidur bayi tidak hanya berpengaruh pada perkembangan fisik, tapi juga sikapnya keesokan hari. Bayi yang tidur cukup tanpa sering terbangun akan lebih bugar dan tidak gampang rewel dan tidak memerlukan tidur siang yang melebihi kebutuhan sesuai dengan perkembangannya.

\section{Kualitas Tidur Berdasarkan Lama Terbangun}

Kualitas tidur bayi ditentukan oleh adanya gangguan tidur, bayi dikatakan mengalami gangguan tidur jika lama terbangunnya dimalam hari lebih dari 1 jam. Hasil analisis data lama bayi terbangun dimalam hari sebelum pemijatan mengalami penurunan dari rata-rata lama terbangun 13,82 menjadi 11,18 setelah dilakukan pemijatan. Hal ini juga sesuai dengan penelitian Martini dkk (2014) bahwa bayi yang diberi ASI sebelum tidur, tidurnya akan lebih nyenyak dibandingkan dengan bayi yang tidak diberi ASI sebelum tidur.

Kebiasaan minum susu sebelum tidur berpengaruh terhadap kualitas tidur bayi karena ASI terbukti mengandung alfa protein yang cukup tinggi, alfa protein merupakan protein utama pada whey protein yang merupakan protein halus dan mudah dicerna. Alfa protein kaya akan asam amino essensial yang sangat berguna untuk tumbuh kembang bayi, terutama tripthopan. Tripthopan adalah asam amino yang berperan dalam proses neurotransmitter dan pengatur pola hidup dimana salah satu fungsinya adalah mengatur pola tidur. Bayi yang sulit tidur atau sering terbangun dari tidurnya karena merasa belum kenyang. Karena itu, penuhi kebutuhan makan dan minum bayi sebelum tidur. Jika kebutuhan fisiknya dipenuhi, si kecil tidak lagi sering terbangun di tengah malam.

Terbangunnya bayi di malam hari sebenarnya merupakan hal yang wajar, bila kurang dari satu jam. Hal ini dikarenakan bayi membutuhkan ASI sebagai sumber nutrisi. Lain halnya dengan bayi yang terjaga di malam hari untuk melakukan aktifitas lain misalnya bermain.

\section{SIMPULAN DAN SARAN Simpulan}

Berdasarkan hasil analisis dan pembahasan yang dikemukakan maka dapat disimpullkan bahwa:Lama tidur bayi sesudah pemijatan mengalami peningkatan 0,32 jam dibandingkan sebelum pemijatan, tidak ada perbedaan yang bermakna antara lama tidur bayi sebelum dan sesudah pemijatan ( $p=$ 0,414 ), Frekuensi terbangun bayi dimalam hari sesudah pemijatan mengalami penurunan 0,82 kali dibandingkan sebelum pemijatan, ada perbedaan yang bermakna antara frekuensi terbangun bayi sebelum dan sesudah pemijatan $(p=0,001)$, Lama terbangun bayi dimalam hari sesudah pemijatan mengalami penurunan 2,64 menit dibandingkan sebelum pemijatan, ada perbedaan yang bermakna antara lama terbangun sebelum dan sesudah pemijatan $(p=0,046)$.

\section{Saran}

Berdasarkan hasil dan kesimpulan penelitian mengenai kualitas tidur bayi, saran yang dapat dipertimbangkan adalah: Meningkatkan pengetahuan tentang pentingnya pijat bayi oleh tenaga kesehatan dengan memberikan informasi dan demonstrasi yang jelas, lengkap dan berkelanjutan, sebagai sasaran yaitu kader posyandu dan ibu-ibu yang memiliki bayi serta keluarga lainnya, Perlu penelitian lebih lanjut mengenai kualitas tidur bayi dengan memperhatikan variabel pengganggu lain seperti lingkungan, nutrisi dan penyakit pada bayi.

\section{DAFTAR RUJUKAN}

Abidin, Z. (2009) Perlindungan Anak dan Implementasinya. Tersedia dalam: http://www.kabarindonesia.com/beritap rint.php. Diakses 2 Oktober 2014

Badan Pusat Statistik \& Macro International (2012) Survei demografi dan kesehatan Indonesia 2007. Calverton, Maryland, USA: BPS dan Macro International 
Graham, J dan Charles, E.S., (2002) Panduan sehat dan bijak menidurkan bayi. Jakarta: Prestasi Pustakaraya

Gunadi, Tri.(2009). My Baby. Jakarta : Penebar plus.

Harley, S. (2003) Tangan-tangan lembut: Pijatan sehat untuk anak. Jakarta: PT. Elex Media Komputindo

Hurlock, E.B (1997) Psikologi perkembangan: suatu pendekatan sepanjang rentang kehidupan, Edisi kelima. Jakarta: Erlangga

Prasetyawati, A.E., (2012) Kesehatan Ibu dan Anak (KIA) dalam Millenium Development Goals (MGDs). Yogyakarta: Nuha Medika

Ria, Lia. (2010). Hubungan PIjat Bayi dengan kualitas tidur bayi umur 6-12 bulan di Desa Kertosari Kecamatan Singorejo Kabupaten Kendal. Skripsi tidak diterbitkan. Program Studi S 1 Keperawatan. Universitas Muhammadiyah Semarang.

Martini, dkk. (20014). Pengaruh pijat bayi terhadap kuantitas tidur bayi usia 3-6 bulan di Desa Munungrejo Kecamatan Ngimbang Kabupaten LamonganTersedia dalam http://stikesmuhla.ac.id/wpcontent/uploads/jurnalsurya/noXVIII/10 9-115-Jurnal-Diah-E.M.pdf, Diakses 4 April 2014.

Musrifatul, U. dan Alimul, A. (2008) Ketrampilan Dasar Praktik Klinik untuk Kebidanan.: Jakarta: Salemba Medika.

Novianti, S.W. (2006) Pengaruh terapi pijat dalam penurunan frekuensi $\mathrm{BAB}$ dan tingkat dehidrasi pada anak usia 0-2 tahun dengan diare di RSUD Cibabat Cimahi. Tersedia dalam http://stikesayani.ac.id/publikasi/ejournal/files/2010/201008/201008003.pdf. Diakses 4 April 2014.

Peraturan Menteri Kesehatan Nomor 1109/MENKES/PER/IX/2007 tentang Penyelenggaraan Pengobatan Komplementer-Alternatif di Fasilitas Pelayanan Kesehatan.

Prasetyono,DS., (2013). Buku Pintar Pijat Bayi. Jogjakarta : Buku Biru

Roesli, U., (2007) Pedoman Pijat Bayi Prematur dan bayi usia 0-3 bulan. Jakarta. Trubus Agro Wijaya

Sastroasmoro, S. dan Ismael, S. (2008) Dasardasar metodelogi penelitian klinis. Jakarta: Sagung Seto

Undang-undang Nomor 36 Tahun 2009 tentang Kesehatan

Undang-undang Nomor 23 Tahun 2002 tentang Perlindungan Anak

Utomo, B. (1988) Kematian bayi dan anak di Indonesia, beberapa implikasi kebijakan. Dalam Singarimbun, M., Ed. Kelangsungan hidup anak. Yogyakarta: Gajah Mada University Press

Widodo, A. (2012) Efektivitas Baby Spa terhadap lamanya tidur bayi usia 3 sampai 4 bulan. Dibuka tanggal 20 agustus 2014 publikasiilmiah.ums .ac.id/bitstream/handle/ 123456789 /3316/12.20AGUS\%20WIDODO.pdf?s equence $=1$. 